\title{
Water and Carbon Budgets of Developing Citrus Fruit
}

\author{
T-B Huang', R.L. Darnell, and K.E. Koch \\ Fruit Crops Department, University of Florida, Gainesville, FL 32611-0511 \\ Additional index words. carbon economy, Citrus madurensis, C. paradisii, phloem, fruit photosynthesis, fruit \\ respiration, translocation, transpiration
}

\begin{abstract}
Water and carbon budgets of individual citrus fruit were determined throughout their growth to quantify the demand for sucrose and water relative to developmental changes. Fruit transpiration, water accumulation, photosynthesis, respiration, and $\mathrm{C}$ gain were measured during this period for grapefruit (Citrus paradisii Macf.) and calamondin (Citrus madurensis Lour.). On a whole-fruit basis, estimated rates of grapefruit transpiration and mean daily water inflow decreased after the first third of development, whereas water apparently was lost freely throughout growth of the smaller, thin-peeled calamondins. Estimates of daily fruit $\mathbf{C}$ import remained relatively similar during the majority of grapefruit growth, increasing rapidly only as fruit neared maturation. A similar trend was observed in calamondins, although rates were more variable. Overall, estimated mean daily water inflow into "developing grapefruit decreased relative to that of sucrose inflow, resulting in a progressively higher ratio of sucrose transport to net water inflow. Values for these ratios rose from $\approx 10$ to $>300 \mathrm{~g}$ sucrose/liter of water, reaching levels of net water and sngar transfer that could both be accommodated by citrus phloem alone. Any additional entry into grapefruit appears to have been offset by xylem back-flow, because no other net water influx was observed.
\end{abstract}

Water and carbon balance of fruit are important to fruit Quality (Ho et al., 1987). Ample water for full cell turgor is essential for maximal expansion and determination of eventual fruit size (Mitchell et al., 1984; Morgan, 1984). Carbon input must be high enough to allow for synthesis of structural components and solute accumulation. The latter is necessary for continued cell expansion and development of fruit flavor.

Fruit water balance is determined by entry of $\mathrm{H}_{2} \mathrm{O}$ via xylem and phloem (Pate et al., 1977, 1978), accumulation in fruit, and losses due to either fruit transpiration (Syvertsen and Albrigo, 1980) and/or xylem back-flow to transpiring leaves or other sinks within the plant (Elfving and Kaufmann, 1972). Water movement into fruit can vary with the stage of fruit development, as well as the rate of fruit transpiration (Boyer, 1985). Substantial quantities may enter via the phloem, and in tomato (Lycopersicon esculentum Mill.) this path is estimated to be the primary avenue of water influx into fruit (Ho et al., 1987). Fruit development also appears to affect the rate of water loss from the fruit surface due to factors such as surface : volume ratio, cuticle thickness (Syvertsen and Albrigo, 1980), stomatal frequency (Blanke and Lenz, 1989), and stomatal responsiveness (Blanke and Leyhe, 1987).

Fruit sugar content depends on import of photosynthetic products and is also influenced by fruit photosynthesis and respiration. Fruit photosynthesis has been documented in a wide range of species (Blanke and Lenz, 1989; Flinn et al., 1977). Photosynthetic $\mathrm{CO}_{2}$ fixation in fruit of green apples (Malus domestica Borkh.), olives (Olea europea L.), and Citrus is estimated to conserve $20 \%$ to $80 \%$ of the $\mathrm{CO}_{2}$ released by dark respiration, depending on the stage of development (Bean and Todd, 1960; Bean et al., 1963; Blanke and Lenz, 1989). Fruit photosynthesis also is calculated to contribute $\approx 15 \%$ of the total carbohydrates used for fruit development in blueberry (Vaccinium ashei Reade) (Birkhold et al., 1992) and 11\% in sour cherry (Prunus cerasus

Received for publication 12 Mar. 1991. Accepted for publication 12 Nov. 1991. Journal Article no. R-02130 from the Florida Agr. Expt. Station. The cost of publishing this paper was defrayed in part by the payment of page charges. Under postal regulations, this paper therefore must be hereby marked advertisement solely to indicate this fact.

1Present address: Council of Agriculture, Executive Yuan, 37 Nan Hai Road, Taipei, Taiwan, ROC.
L.) (Kappes, 1985). Contributions of fruit photosynthesis vary widely during development. Substantial rates of carbon fixation (14 to $22 \mu \mathrm{mol} \mathrm{CO}_{2} / \mathrm{g}$ fresh weight per hour above respiratory $\mathrm{CO}_{2}$ loss) have been reported in very young fruit of blueberry (Birkhold et al., 1991). Respiratory rates on a dry-weight basis also typically decrease during fruit development. Although this process provides energy for metabolic conversions, growth, and maintenance processes within the fruit (Jones, 1981), it reduces the amount of $\mathrm{C}$ available for accumulation of dry matter and sugar. For example, DeJong and Walton (1989) estimated that peach [Prunus persica (L.) Batsch] fruit respired $16 \%$ to $21 \%$ of their total fruit dry weight during development.

Most research on the relationship between water use and C balance has centered on leaves (Sinclair and Allen, 1982) or whole plants (Cohen et al., 1987). Other work has focused on respiration and water loss from harvested fruit (Daito and Sate, 1984). Few studies have addressed both water and C use in growing fruit (Ho et al., 1987; Pate et al., 1977; People et al., 1985) or developmental changes in the relationship between them. When is $\mathrm{C}$ translocation into fruit highest? When is water use maximal? How do the two compare? Are both maximal during early growth, as for tomato (Ho et al., 1987)?

The situation in citrus fruit also poses a special problem. Water loss from juice sacs appears to be extremely limited. Tritiated water showed little turnover within 3 days after entry into sacs (Mantell et al., 1980), and Kaufmann (1970) described the sacs as being essentially isolated from the path of water movement through fruit. This situation could have significant implications for water conservation and sugar accumulation. Sugar entry into phloem-free juice sacs may involve some form of mass flow (Koch and Avigne, 1990). However, actual flow appears to be limited, and water entry into juice tissues of a grapefruit does not exceed 1 to $2 \mathrm{ml} \cdot$ day $^{-1}$ (Koch and Avigne, 1990). Citrus fruit also has substantial phosphoenol pyruvate (PEP) carboxylase activity, which may increase the capacity for refixation of respiratory $\mathrm{CO}_{2}$ by juice sacs (Yen, 1987).

The purpose of our research was to quantify developmental changes in the import, loss, and balance of water and $\mathrm{C}$ during growth of citrus fruit and clarify the relationship between movement of the water and $\mathrm{C}$ into the fruit during this period. Grapefruit and calamondin were examined throughout their growth 
with respect to transpiration, water influx, respiration, fruit photosynthesis, C gain, and water-use efficiency (WUE). Grapefruit and calamondin were selected to represent a broad range in size and structural features in citrus fruit.

\section{Materials and Methods}

Plant materials. Fruit for the experiments were produced on 10-year-old grapefruit trees and 6-year-old calamondin trees in 50- and 10-liter containers, respectively, using Metro Mix 500 medium (W.R. Grace Co., Cambridge, Mass.). Calamondins were grown in a greenhouse, and grapefruit trees were positioned on adjacent, outdoor gravel beds at the Univ. of Florida, Gainesville. Both were watered daily to soil saturation. $\mathrm{Nu}$ trients were applied at 2- to 3-week intervals as a commercial formula (Peter's; W.R. Grace \& Co., Fogelsburg, Pa.) containing $20 \mathrm{~N}-5.6 \mathrm{P}-11 \mathrm{~K}$ and micronutrients. Each grapefruit tree bore several fruit, and calamondin trees had $1 \approx 20$ fruit each.

Fruit transpiration and $C$ exchange. Transpirational water loss and net $\mathrm{CO}_{2}$ exchange were measured periodically throughout fruit development. Ten fruit were examined at each sampling time. Measurements were conducted every 15 days for the first 2 to 3 months after, anthesis and at 45- to 60-day intervals thereafter. Individual fruit (tagged at anthesis) were enclosed in plexiglass chambers (sizes varied with fruit) and continuously flushed with ambient air at $500 \mathrm{ml} \cdot \mathrm{min}^{-1}$. Light was provided at 800 to $100 \mu \mathrm{mol} \cdot \mathrm{m}^{-2} \mathrm{~s}^{-1}$ photosynthetic photon flux (PPF) by a 400-W high-pressure sodium vapor lamp (Lucalox; General Electric, Cleveland) to one side of the fruit, and temperature was maintained throughout light and dark measurements at 20 to $22 \mathrm{C}$. Transpirational water loss from fruit was calculated as the difference between water content of air before and after movement through the chamber. Relative humidity of the airstream was measured by a condensation dewpoint hygrometer (System 1100DP; General Eastern Instruments Co., Watertown, Mass.) and ranged from 53\% to $57 \%$ for air entering chambers. Respiratory $\mathrm{C}$ loss from fruit was measured by quantifying increases in $\mathrm{CO}_{2}$ concentration over time after switching the chamber airflow to a recycling mode. The $\mathrm{CO}_{2}$ samples were analyzed with a gas chromatography (Model 1200; Fisher Scientific Co., Pittsburgh). Water and C losses from fruit were quantified in light and darkness to facilitate estimation of 24-h water and $\mathrm{C}$ balances (assuming a 12-h photoperiod). For sampling in darkness, the chamber was covered with several layers of aluminum foil and allowed to equilibrate for $20 \mathrm{~min}$ before measurements were begun. Constant rates of water and C loss were observed after light-dark transition periods of this duration. Fruit photosynthesis was calculated as the difference between net $\mathrm{C}$ exchange in light and darkness.

Fruit water and $C$ content. Fresh and dry weights of fruit were determined at each sampling point during the experiment. Each fruit was weighed immediately following measurements of transpiration and net $\mathrm{CO}_{2}$ exchange. Dry weight was measured after samples were cut into $\approx 3$ - to 5 -g pieces and dried at 78 to $80 \mathrm{C}$ for 4 days. Water content in fruit was calculated by subtracting dry weight from fresh weight. Samples were ground to a fine powder in liquid nitrogen and lyophilized. Total $\mathrm{C}$ content of dried fruit tissues was determined by combustion, oxidation, and quantification by gas chromatography (NA 1500; Carlo Erba Strumentazione, Italy).

Calculation of fruit water and $C$ budgets. Values were estimated as follows: Mean daily water accumulation $\left(\mathrm{g} \mathrm{H}_{2} \mathrm{O} /\right.$ fruit per day) was the difference between mean daily fresh weight accumulation and mean daily dry weight accumulation. Both daily means were calculated by dividing total increases observed during a given period by the number of days ( $t$ ) between measurements:

$$
\begin{gathered}
\text { Mean daily } \mathrm{H}_{2} \mathrm{O} \text { accumulation }=\text { [total } \mathrm{H}_{2} \mathrm{O} \text { content }\left(\mathrm{t}_{2}\right)- \\
\text { total } \left.\mathrm{H}_{2} \mathrm{O} \text { content }(\mathrm{tl})\right] /\left(\mathrm{t}_{2}-\mathrm{t}_{1}\right)
\end{gathered}
$$

Mean daily transpiration ( $\mathrm{g} \mathrm{H}_{2} \mathrm{O}$ /fruit per day) was estimated from the mean of daily transpiration rates calculated for the first $\left(\mathrm{t}_{1}\right)$ and last $\left(\mathrm{t}_{2}\right)$ day of a given period. Each was the sum of total water estimated to have been transpired during $12 \mathrm{~h}$ in the light and $12 \mathrm{~h}$ in the dark:

$$
\begin{gathered}
\text { Mean daily transpiration }=\left[\text { daily transpiration rate }\left(\mathrm{t}_{1}\right)+\right. \\
\text { daily transpiration rate } \left.\left(\mathrm{t}_{2}\right)\right] / 2
\end{gathered}
$$

Mean daily water inflow ( $\mathrm{g} \mathrm{H}_{2} \mathrm{O}$ /fruit per day) was estimated by adding the mean daily water accumulation and the estimated mean daily transpiration by fruit $($ Eq. [1] + [2]). Potential effects of growing environment on water accumulation measurements presumably would have been minimal here because trees were provided with ample water for fruit expansion on a 24-h basis. Possible xylem back-flow was not included in this calculation; thus, values represent net water use and minimum estimates of total water inflow.

Mean daily $\mathrm{C}$ accumulation (mg $\mathrm{C} /$ fruit per day) was calculated by dividing the increase in total fruit $\mathrm{C}$ during a given period of time by the number of days $(\mathrm{t})$ between measurements. Fruit Cat each point was calculated using the ratio of elemental $\mathrm{C}$ : unit dry weight.

$$
\begin{aligned}
& \text { Mean daily } \mathrm{C} \text { accumulation }=\left[\text { total } \mathrm{C} \text { content }\left(\mathrm{t}_{2}\right)-\right. \\
& \text { total } \mathrm{C} \text { content }(\mathrm{tl})] /\left(\mathrm{t} 2-\mathrm{t}_{1}\right)
\end{aligned}
$$

Mean daily $\mathrm{C}$ loss ( $\mathrm{mg} \mathrm{C} /$ fruit per day) was estimated as the mean of daily $C$ losses estimated for the first $\left(t_{1}\right)$ and last $\left(t_{2}\right)$ day of a given period. Each was the sum of total net respiratory $\mathrm{C}$ release calculated to occur during $12 \mathrm{~h}$ in the light and $12 \mathrm{~h}$ in the dark. Fruit photosynthesis was included in measurements of respiration in the light, and $\mathrm{CO}_{2}$ exchange data were converted to $\mathrm{C}$ equivalents.

$$
\begin{gathered}
\text { Mean daily } \mathrm{C} \text { loss }=\left[\text { daily respiration }\left(\mathrm{t}_{1}\right)+\right. \\
\text { daily respiration } \left.\left(\mathrm{t}_{2}\right)\right] / 2
\end{gathered}
$$

Mean daily $\mathrm{C}$ import ( $\mathrm{mg} \mathrm{C} /$ fruit per day) was estimated from the sum of the mean daily $\mathrm{C}$ accumulation and the mean daily C loss (Eq. [3] + [4]). Although C accumulation (Eq. [3]) is based on dry weight increases, possible effects of growing temperatures in the present study were considered minimal (see estimates in results).

WUE (mg dry weight/g $\mathrm{H}_{2} \mathrm{O}$ ) was calculated by dividing mean daily dry weight accumulation by mean daily water inflow.

Carbohydrate cost (g sucrose/g dry weight) for fruit growth was estimated by dividing mean daily $\mathrm{C}$ import by mean daily dry weight gain, then converting to sucrose equivalents.

Mean daily fruit photosynthetic contribution (mg C/fruit per day) was the mean of daily $\mathrm{C}$ gain via fruit photosynthesis during the first and last day of a given period. Individual values were estimated by subtracting net $\mathrm{CO}_{2}$ exchange in the light from that in the dark, then multiplying by an assumed 12-h photoperiod.

Mean daily sucrose import (g sucrose/fruit per day) was the mean daily $\mathrm{C}$ import converted to sucrose equivalents.

All calculations assumed a 12-h photoperiod, saturating PPF, and constant day/night temperatures of $21 \mathrm{C}$ at each stage of development. The estimated $\mathrm{C}$ and water budgets represent ef- 
fects of fruit development on relative changes in $\mathrm{C}$ and water use and provide a framework on which future work examining environmental influences can be based.

\section{Results}

Water budget. Rates of transpirational water loss from fruit per unit fresh weight decreased-continuously during growth of both grapefruit and calamondin, particularly during the first 2 months after anthesis (Fig. $1 \mathrm{Al}$ and $\mathrm{Bl}$ ). In grapefruit, transpiration rates were similar in light and dark during the majority of development (Fig. $1 \mathrm{Al}$ and A2), but in calamondin, water loss was significantly higher in light during much of fruit growth (Fig. 1 B1 and B2). In grapefruit, whole fruit transpiration rate increased rapidly during stage I and early stage II; coinciding with substantial gains in fruit volume and surface area. A decrease in rate of net water loss per fruit was evident thereafter in grapefruit, with relatively low rates of water loss maintained throughout subsequent expansion and maturation (Fig. 1A2). In contrast, whole-fruit transpirational water loss from calamondins increased gradually until the beginning of stage III (fruit at the green-to-orange transition), then declined during final

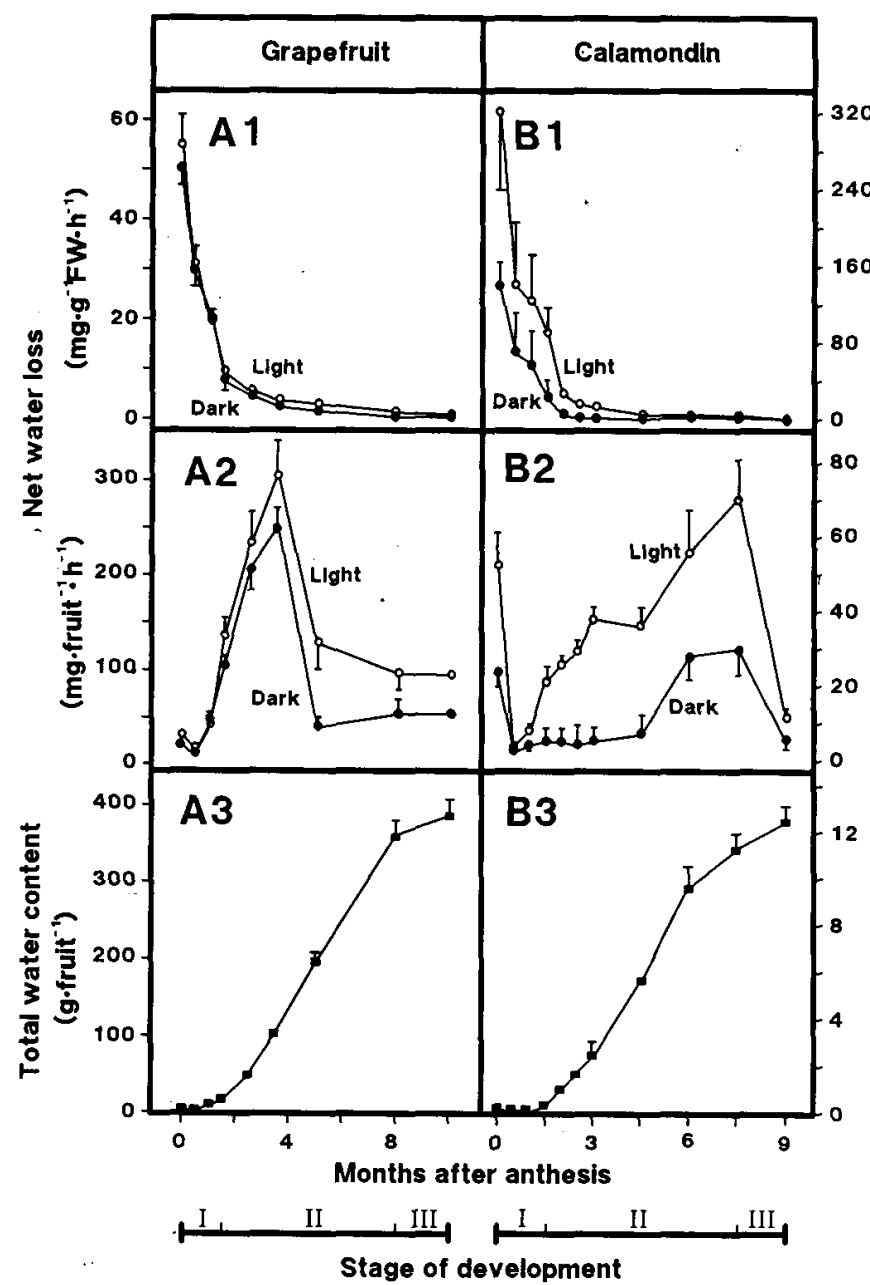

Fig. 1. Water loss and accumulation by developing fruit of grapefruit and calamondin: (A1) and (B1) transpiration per gram fresh weight, (A2) and (B2) transpiration per fruit, (A3) and (B3) total water content in fruit. Intact, attached fruit were used for all measurements. Transpiration was measured in the light $\left(800\right.$ to $1000 \mu \mathrm{mol} \cdot \mathrm{m}^{-2} \cdot \mathrm{s}^{-1}$ $\mathrm{PPF}$ ) and dark at 20 to $22 \mathrm{C}$ with $53 \%$ to $57 \%$ relative humidity. Error bars denote SE of 10 fruit. fruit maturation (Fig. 1B2). Total water content in both grapefruit and calamondin fruit increased most rapidly during stage $\mathrm{H}$ (major part of expansion) (Fig. $1 \mathrm{~A} 3$ and B3).

Mean daily water accumulation rate in developing fruit of grapefruit increased gradually and peaked at $\approx 2 \mathrm{~g} /$ fruit per day during stage II (from 2.5 to 8 months after anthesis) (Fig. 2A1). Mean water accumulation rate dropped to less than one-seventh of this amount during stage III (maturation). Developmental changes in rates of water accumulation by calamondin were most rapid during the expansion stage ( 4.5 to 6 months after anthesis), acquiring little new water during the final maturation stage $(\approx 0.01 \mathrm{~g} /$ fruit per day) (Fig. $2 \mathrm{~B} 1)$. Estimated rates of water loss by transpiration from both citrus fruit (Fig. 2 A2 and B2) changed during development in a manner similar to those of total apparent daily water inflow (Fig. 2 A3 and B3). This likeness was due to the low rate of water accumulation relative to the estimated rate of transpirational loss from the fruit. Developmental changes in fruit water accumulation were considered unlikely to have been significantly affected by the growing environment used here, because any diurnal deficiencies in fruit

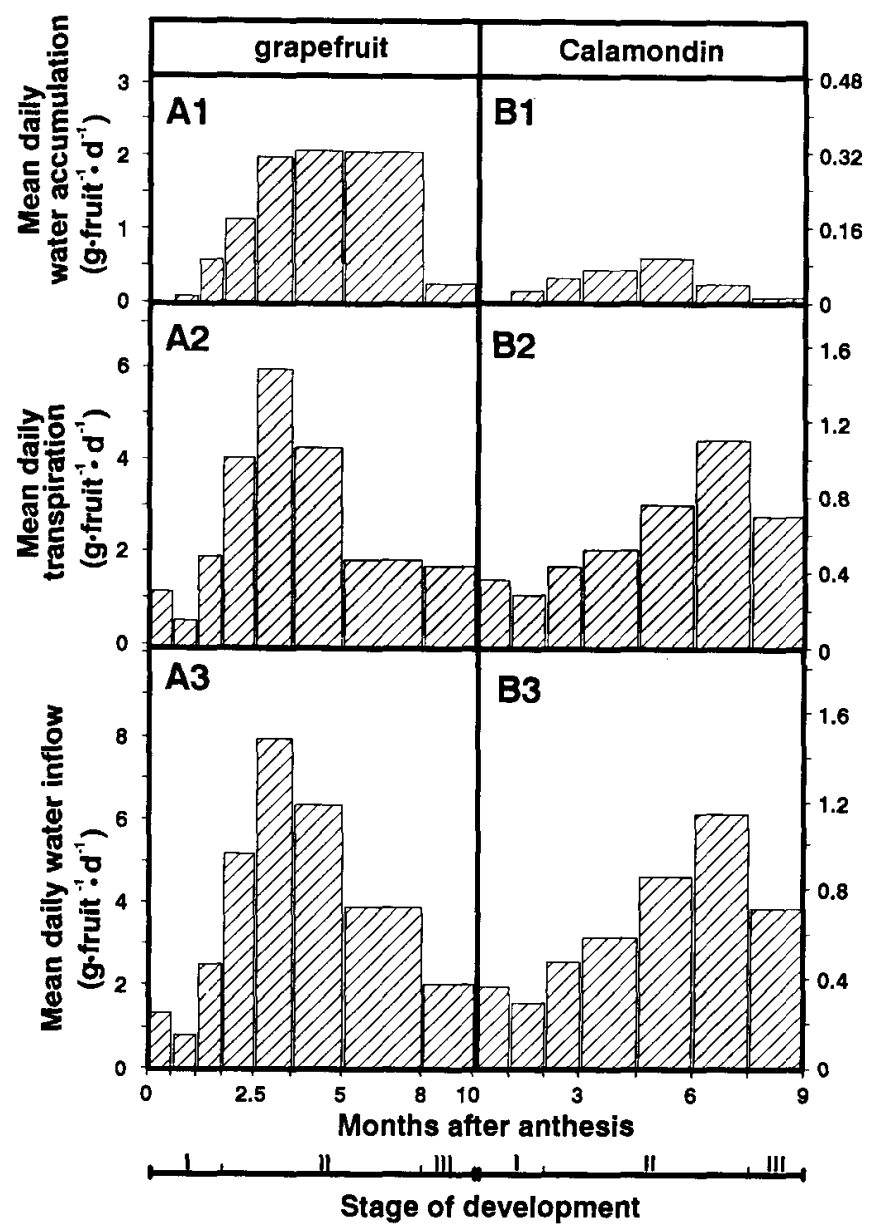

Fig. 2. Estimated rates of net water use by developing fruit of grapefruit and calamondin: (A1) and (B1) mean daily water accumulation rate, $(\mathbf{A} 2)$ and $(\mathbf{B} 2)$ estimated mean daily transpiration rate, $(\mathbf{A} 3)$ and (B3) estimated mean daily water inflow. Daily transpiration was estimated using measured values from Fig. 1 and assuming a 12-h light/12-h dark period. Histograms thus represent mean rates calculated for time periods (width of bars) between sample points, which were as follows: $0,0.5,1,1.5,2.5,3.5,5,8$, and 10 months after anthesis for grapefruit, and $0,1,2,3,4.5,6,7.5$, and 9 months after anthesis for calamondin. Error bars denote SE of 10 fruit. 
water balance would presumably have been countered by nocturnal dehydration and expansion by fruit of well-irrigated trees.

Carbon budget. Net $\mathrm{CO}_{2}$ loss per unit fresh weight decreased markedly during growth for both fruit (Fig. $3 \mathrm{Al}$ and $\mathrm{Bl}$ ). Calamondin exhibited a higher capacity for $\mathrm{CO}_{2}$ fixation in the light than grapefruit, resulting in little or no net loss of respiratory $\mathrm{CO}_{2}$ in the light during most of fruit development.' In fact, during the latter part of stage $\mathrm{I}$, positive $\mathrm{CO}_{2}$ exchange values were noted (Fig. 3B1).

Developmental changes in net $\mathrm{CO}_{2}$ loss per fruit differed between grapefruit and calamondin (Fig. 3 A2 and B2). Grapefruit size continued to increase throughout much of its development; however, rate of $\mathrm{CO}_{2}$ release did not follow the same pattern. Losses of $\mathrm{CO}_{2}$ from fruit increased until 2.5 months after anthesis but did not rise substantially again until final stages of maturation (Fig. 3A2). In contrast. changes in net $\mathrm{CO}_{2}$ losses from whole calamondin fruit followed those of fruit growth more closely when based on $\mathrm{CO}_{2}$ release in the dark. In the light, however, $\mathrm{CO}_{2}$ release per fruit remained low during the expansion period, and positive net photosynthesis was periodically observed. Losses of $\mathrm{CO}_{2}$ in the light increased toward fruit maturation (Fig. 3B2).

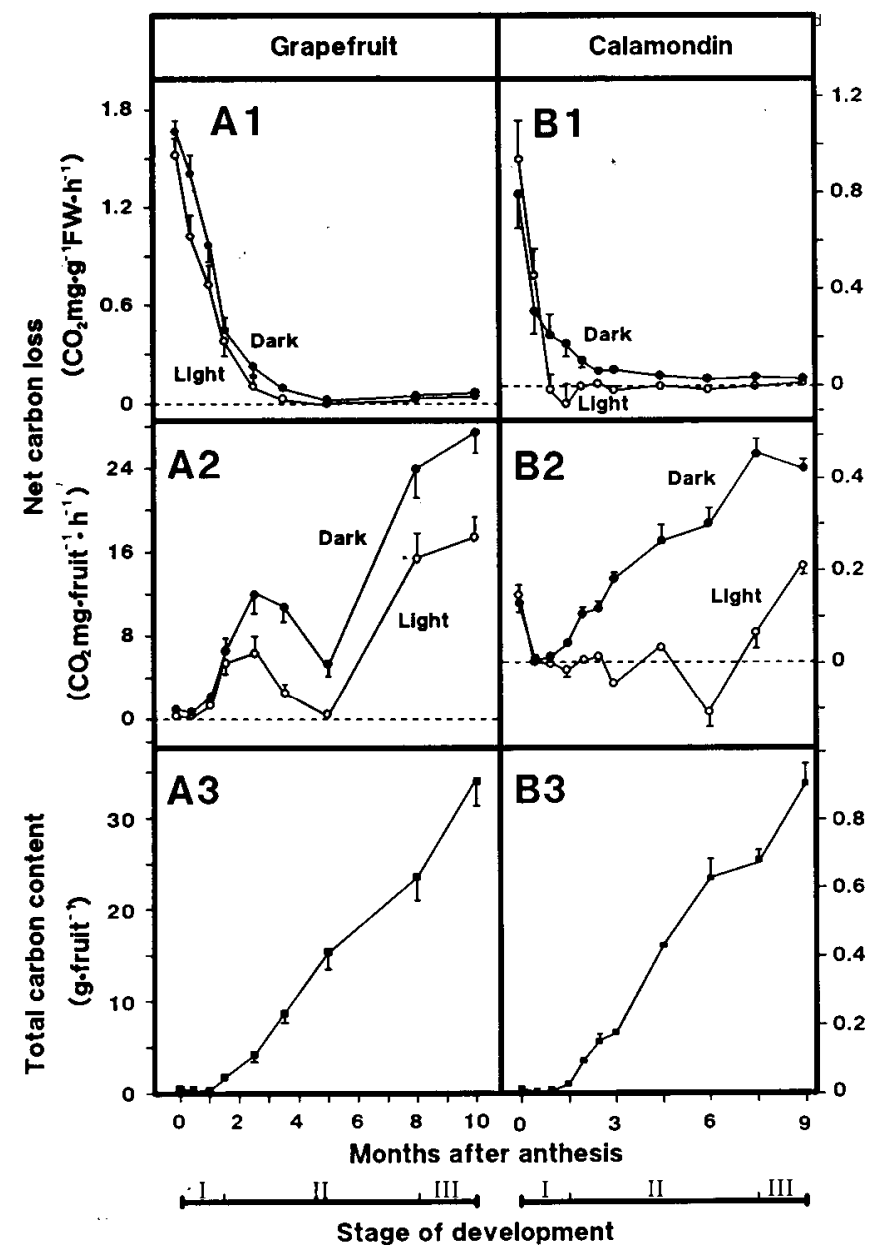

Fig. 3. Carbon loss and accumulation by developing fruit of grapefruit and calamondin: (A1) and (B1) net $\mathrm{CO}_{2}$ loss per gram fresh weight, (A2) and (B2) net $\mathrm{CO}_{2}$ loss per fruit, (A3) and (B3) total $\mathrm{C}$ content in fruit. Intact, attached fruit were used for all measurements. Carbon dioxide exchange was measured in the light (800 to 1000 $\mu \mathrm{mol} \cdot \mathrm{m}^{-2} \cdot \mathrm{s}^{-1} \mathrm{PPF}$ ) and dark at 20 to $22 \mathrm{C}$ with $53 \%$ to $57 \%$ relative humidity. Error bars denote SE of 10 fruit.
The increase of total $\mathrm{C}$ content in developing fruit (Fig. 3 A3 and B3) was proportional to dry weight (data not shown). Elemental $\mathrm{C}$ content remained stable throughout development of grapefruit and calamond in fruit and constituted $\approx 44 \%$ and $46 \%$ of the dry weight in peel and pulp, respectively. Total $\mathrm{C}$ content of both fruit increased slowly at first and rose more rapidly thereafter.

Mean daily $\mathrm{C}$ accumulation in developing grapefruit and calamondin fruit (Fig. $4 \mathrm{Al}$ and $\mathrm{Bl}$ ) did not appear to be closely related to estimates of mean daily $\mathrm{C}$ loss via respiration (Fig. 4 A2 and B2). In grapefruit, estimated mean daily $C$ loss per fruit increased during early growth then dropped to about half at 3.5 to 5 months after anthesis. Carbon was apparently lost at increasing rates toward fruit maturation and was maximal in maturing fruit (Fig. 4A2). Estimated mean daily C loss from calamondin fruit increased continuously throughout development (Fig. 4B2).

Estimates of mean daily $\mathrm{C}$ import by both fruit (Fig. 4 A3 and B3) more closely resembled daily $\mathrm{C}$ accumulation (Fig. 4

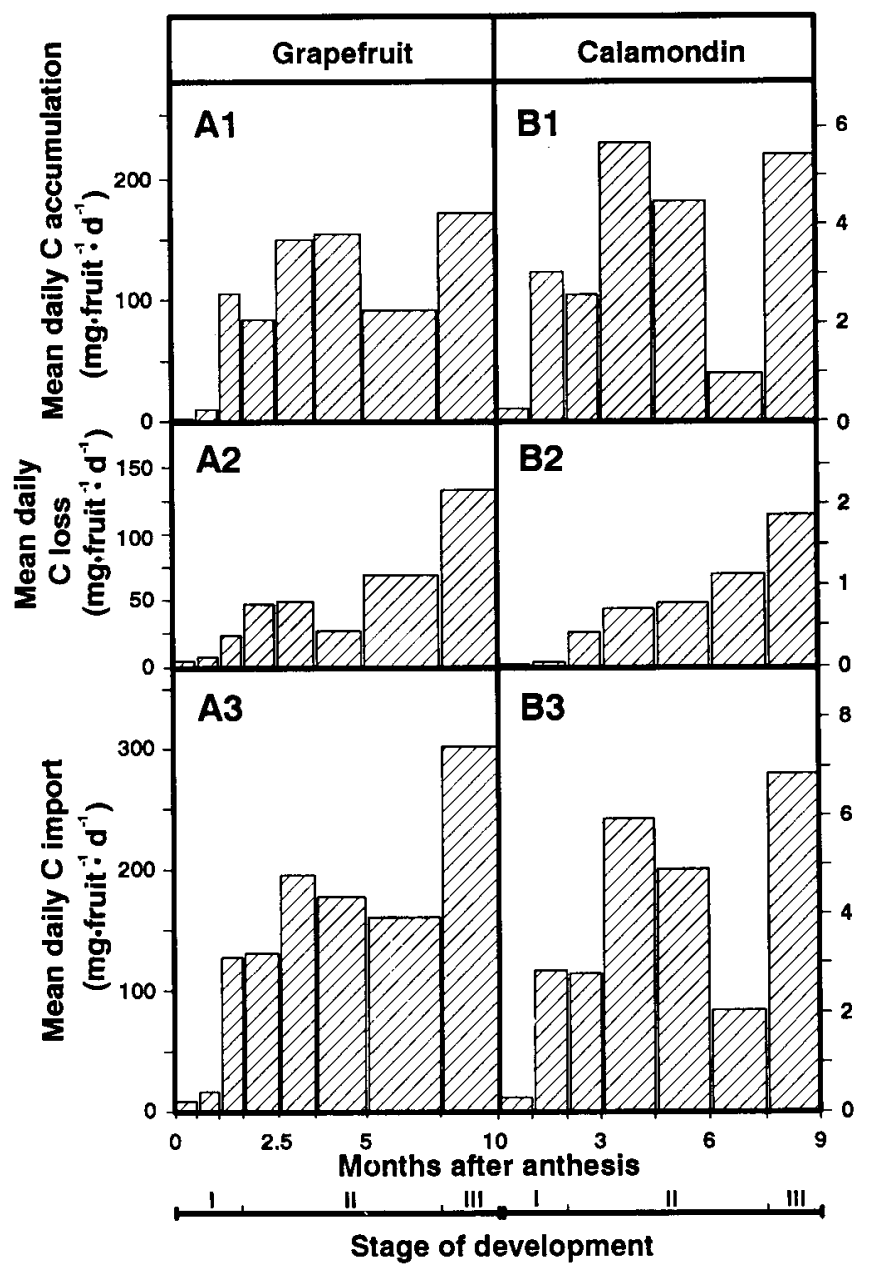

Fig. 4. Estimated rates of $\mathrm{C}$ use by developing fruit of grapefruit and calamondin: (A1) and (B1) mean daily $\mathrm{C}$ accumulation rate, (A2) and (B2) estimated mean daily $C$ loss, (A3) and (B3) estimated mean daily $\mathrm{C}$ import. Mean daily $\mathrm{C}$ loss and total $\mathrm{C}$ import were estimated using measured values from Fig. 3 and assuming a 12-h light/12-h dark period. Histograms thus represent mean rates calculated for time periods (width of bars) between sample points, which were as follows: $0,0.5,1,1.5,2.5,3.5,5,8$, and 10 months after anthesis for grapefruit, and $0,1,2,3,4.5,6,7.5$, and 9 months after anthesis for calamondin. Error bars denote SE of 10 fruit. 
$\mathrm{Al}$ and $\mathrm{Bl}$ ) than estimated daily $\mathrm{C}$ loss via respiration (Fig. 4 $\mathrm{A} 2$ and B2). The estimated mean daily $\mathrm{C}$ import was fairly constant during the major part of fruit growth in grapefruit, due, in part, to the rapid increase in $\mathrm{C}$ accumulation after the first month of growth and the relatively low estimated rate of $\mathrm{CO}_{2}$ release until the last 2 months of development. In calamondin, estimated mean daily fruit $\mathrm{C}$ import also rose early in development without increasing further until late stage 111 .

The $\mathrm{C}$ accumulation component of these values may have been affected somewhat by the influence of growing temperatures on dry weight gain, but these effects were estimated to be relatively minimal. Generally small contributions by fruit photosynthesis (typically $<10 \%$ or $15 \%$ of the $\mathrm{C}$ requirement for grapefruit and calamondin, respectively) indicated that substantial change in fruit dry weight was not likely to arise from this source under the conditions examined here. $\mathrm{A}_{10}$ of 2 was used to calculate possible changes in dry weight that could be associated with altered respiratory rates. These introduced a potential error of $\approx 13 \%$ into midsummer estimates of $\mathrm{C}$ import for both fruit (during the period from 2.5 to 5.0 months after anthesis in grapefruit and 3.0 to 6.0 months in calamondins) and $\approx 15 \%$ during the final 2 months of development in grapefruit only. These were not of a magnitude sufficient to affect conclusions described here.

WUE and carbohydrate cost. Profiles of developmental change in estimated WUE of grapefruit and calamondin fruit showed some similarities; however, overall values from these fruit differed markedly from one another throughout growth (Table 1). Maturing grapefruit (stage III) showed extensive water conservation, accumulating $\approx 190 \mathrm{mg}$ of dry matter for each $1 \mathrm{~g}$ of apparent water influx into the fruit. WUE in these fruit also rose during the period shortly before the onset of fruit expansion, although values remained substantial throughout grapefruit growth. Two peaks in estimated WUE were evident at similar points in calamondin development, but means at all stages were consistently $22 \mathrm{mg}$ or less dry weight/g of water. Fruit of grapefruit and calamondin apparently needed $<2 \mathrm{~g}$ sucrose to produce 1 g dry matter during most of development. Young ovules less ; han 0.5 month after anthesis apparently had a higher carbohydrate cost per gram of dry weight than did fruit at all other developmental stages (3.5 and $4.9 \mathrm{ggg}^{-1}$ dry weight in grapefruit and calamondin fruit, respectively).

Sugar/water influx into fruit. The ratio of estimated mean daily sucrose influx to that of water ranged from 2 to $24 \mathrm{~g}$ sucrose/liter of water throughout calamondin growth (Table 2). However, in grapefruit these values increased from 12 to $>300$ g.liter ${ }^{-1}$ water. This indicates net inflow of a nearly $1 \mathrm{M}$ sucrose solution during final grapefruit development (stage III), unless additional water entry was offset by xylem back-flow. Results for maturing grapefruit are consistent with earlier studies of juice sacs during this period (Koch and Avigne, 1990; Koch et al., 1986).

\section{Discussion}

Water budget. The decrease in water loss per unit fresh weight observed during citrus fruit growth (Fig. $1 \mathrm{Al}$ and $\mathrm{Bl}$ ) is consistent with the reduction in stomatal density reported to occur as fruit expand (Blanke and Lenz, 1989; Soule and Grierson, 1986). In addition, cuticle thickness typically increases during citrus fruit growth (E1-Otmani et al., 1986; Kolattukudy, 1984); also, Syvertsen and Albrigo (1980) have indicated that decreases in fruit water loss are coincident with cuticle formation. These processes may have occurred earlier and/or to a greater extent in grapefruit, because whole-fruit transpiration dropped early in grapefruit without doing so until near maturity in calamondins. Stomatal density would have dropped less in the small-fruited calamondins than in grapefruit, however, and differences between transpiration in light and darkness remained significant in calamondin (Fig. 1B2). Developmental changes in estimated whole-fruit transpiration per day (Fig. 2 A2 and B2) superseded those of fruit water accumulation (Fig. $2 \mathrm{Al}$ and $\mathrm{Bl}$ ), thus altering peak periods of estimated daily fruit water use (influx) (Fig. 2 A3 and B3).

Carbon budget. The drop in fruit $\mathrm{CO}_{2}$ loss per unit weight

Table 1. Developmental changes in estimated fruit WUE and carbohydrate costs of grapefruit and calamondin. $\mathbf{z}$

\begin{tabular}{|c|c|c|c|c|}
\hline \multirow{2}{*}{$\begin{array}{l}\text { Months } \\
\text { after } \\
\text { anthesis }\end{array}$} & \multicolumn{2}{|c|}{ Grapefruit } & \multicolumn{2}{|c|}{ Calamondin } \\
\hline & 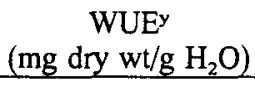 & $\begin{array}{l}\text { Carbohydrate costw } \\
\text { (g sucrose/g dry wt) }\end{array}$ & 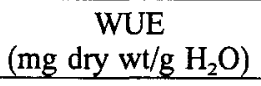 & $\begin{array}{l}\text { Carbohydrate cost } \\
\text { (g sucrose/g dry wt) }\end{array}$ \\
\hline $\begin{array}{l}0.0-0.5 \\
0.5-1.0 \\
1.0-1.5 \\
1.5-2.5\end{array}$ & $\begin{array}{r}4 \pm 2 \\
29 \pm 12 \\
96 \pm 21 \\
37 \pm 9\end{array}$ & $\begin{aligned} & \text { Stage I } \\
3.5 \pm 0.6 & \pm 0.3 \\
2.0 \pm 0 & \pm 0.3 \\
1.3 \pm 0.2 & \pm 0.2\end{aligned}$ & $\begin{array}{r}1 \pm 0 \\
8 \pm 2 \\
12 \pm 6 \\
22 \pm 11\end{array}$ & $\begin{array}{l}4.9 \pm 0.7 \\
1.2 \pm 0.3 \\
1.1 \pm 0.2 \\
1.1 \pm 0.1\end{array}$ \\
\hline $\begin{array}{l}2.5-3.5 \\
3.5-5.0 \\
5.0-8.0 \\
2.5-4.5 \\
4.5-6.0 \\
6.0-7.5\end{array}$ & $\begin{array}{c}43 \pm 11 \\
56 \pm 9 \\
54 \pm 12 \\
\cdots-- \\
-- \\
--\end{array}$ & $\begin{array}{c}\quad \text { Stage II } \\
1.4 \pm 0.2 \\
1.3 \pm 0.1 \\
1.9 \pm 0.3 \\
\cdots \\
--- \\
\cdots\end{array}$ & $\begin{array}{r}\cdots \\
\cdots \\
18 \pm 9 \\
12 \pm 7 \\
2 \pm 1\end{array}$ & $\begin{array}{c}-- \\
\cdots \\
1.2 \pm 0.1 \\
1.2 \pm 0.2 \\
2.2 \pm 1.4\end{array}$ \\
\hline $\begin{array}{l}8.0-10.0 \\
7.5-9.0 \\
\end{array}$ & $\begin{array}{c}193 \pm 45 \\
-- \\
\end{array}$ & $\begin{array}{c}\text { Stage III } \\
1.9 \pm 0.4 \\
\ldots \\
\end{array}$ & $17 \pm 11$ & $1.4 \pm 0.3$ \\
\hline
\end{tabular}

${ }^{2}$ Values are the means of 10 estimates ( \pm SE where shown).

YWUE was calculated by dividing mean daily dry weight accumulation by estimated mean daily water inflow.

wCarbohydrate cost was calculated by dividing estimated mean daily $\mathrm{C}$ import by mean daily dry weight gain, then converting to sucrose equivalents. 
Table 2. Developmental changes in fruit and the estimated ratio of net sucrose inflow : water influx. ${ }^{2}$

\begin{tabular}{lcc}
\hline \hline \multirow{2}{*}{$\begin{array}{c}\text { Months } \\
\text { after } \\
\text { anthesis }\end{array}$} & \multicolumn{2}{c}{$\begin{array}{c}\text { Mean daily sucrose : water influx } \\
\text { (g sucrose/liter } \mathrm{H}_{2} \mathrm{O} \text { ) }\end{array}$} \\
\cline { 2 - 3 } & Grapefruit & Calamondin \\
$0.0-0.5$ & Stage I & 3 \\
$0.5-1.0$ & 12 & 5 \\
$1.0-1.5$ & 53 & 12 \\
$1.5-2.5$ & 118 & 24 \\
& 55 & \\
$2.5-3.5$ & Stage II & -- \\
$3.5-5.0$ & 52 & $\cdots$ \\
$5.0-8.0$ & 59 & -- \\
$2.5-4.5$ & 85 & 15 \\
$4.5-6.0$ & $\cdots$ & 11 \\
$6.0-7.5$ & --- & 2 \\
& $-\cdots$ & 20 \\
$8.0-10.0$ & Stage III & \\
\hline
\end{tabular}

${ }^{2}$ Values are calculated from the means of 10 samples.

yean daily sucrose water influx was calculated by converting the mean daily $\mathrm{C}$ import to sucrose equivalents and dividing by estimated mean daily water inflow. Values for a given period are the means of estimates for the first and last day.

n both citrus fruit (Fig. $3 \mathrm{Al}$ and $\mathrm{Bl}$ ) is consistent with data on early development of other citrus ovaries (Soule and Grierson, 1986). Similar results have also been noted for apple fruit, in which dark respiration declines from $120 \mathrm{ng} \mathrm{CO}_{2} / \mathrm{g}$ of fresh weight per sec during initial growth to $<3 \mathrm{ng} \mathrm{CO} / \mathrm{g}$ of fresh weight per sec at final maturation (Jones, 1981). In contrast, little change in $\mathrm{CO}_{2}$ production per unit fresh weight has been reported to occur during tomato fruit growth (Wolterbeek et al., 1987).

Developmental changes in whole-fruit respiratory $\mathrm{CO}_{2}$ losses differed between grapefruit and calamondin (Fig. 3 A2 and B2), increasing continuously as calamondins enlarged, but doing so only during the first and final portions of grapefruit development. Previous studies of citrus fruit also show that, overall, respiratory $\mathrm{C}$ loss per fruit typically increases during fruit growth (Soule and Grierson, 1986; Flinn et al., 1977). However, rates of $\mathrm{C}$ accumulation and estimated $\mathrm{C}$ loss were not closely linked in grapefruit (Fig. $3 \mathrm{Al}$ and $\mathrm{Bl}$ ). Grapefruit juice sacs may represent a special situation during their rapid expansion phase, because sucrose (and water) entry may involve little metabolic cost (Koch and Avigne, 1990). Dry weight additions to fruit at this stage shift from peel to juice sacs, which appear to expand via inflow of relatively unaltered phloem sap.

Overall, changes in estimated rates of mean daily $\mathrm{C}$ import by growing grapefruit due to developmental changes alone are minimal during the 6 months following most rapid cell division (Fig. 4 A3 and B3). We are aware that our estimates of developmental changes in these values may include some influence of growing environment, particularly the possible effect of temperatures on $\mathrm{C}$ accumulation by fruit. However, mean daily temperatures during the major part of fruit growth were similar to those used for other developmental measurements, and possible error in $\mathrm{C}$ import was estimated at $15 \%$ or less during specific periods in midsummer or winter (see estimates described in Results). This level of potential influence on estimates of developmental changes is considerably less than that needed to affect conclusions described here.

WUE and carbohydrate cost. Dual peaks in estimated WUE before and after the expansion phase (stage II) indicated that C import by fruit did not keep pace with that of water influx during this period of rapid fresh weight gain (Table 1). Highest WUE was observed during final growth stages of grapefruit. Data here and elsewhere (Koch and Avigne, 1990; Koch et al., 1986) indicate sugars can enter grapefruit and juice sacs at this stage of development with minimal net water inflow. Estimated WUE of grapefruit was also consistently higher than that of calamondins, with cumulative values (calculated from Table 1) of 64 and $11 \mathrm{mg}$ dry weight/g of $\mathrm{H}_{2} \mathrm{O}$, respectively, under experimental conditions used here. Previous studies showed that WUE of legume fruits ranged from $125 \mathrm{mg}$ dry weight/g of $\mathrm{H}_{2} \mathrm{O}$ in developing cowpea [Vignia unguiculata (L.) Walp. subsp. unguicalata] fruit (People et al., 1985), to $36 \mathrm{mg}$ dry weight/g of $\mathrm{H}_{2} \mathrm{O}$ in pea (Pisum sativum L.) fruit (Flinn et al., 1977). The lesser values are more typical of other legumes (Pate et al., 1977). The 6- to 8-fold higher rates of water loss per gram of fruit weight for calamondin fruit relative to grapefruit are probably due to several factors, including the higher surface : volume ratio in the smaller fruit, the different stomatal density among fruit of citrus species (Turrel and Klotz, 1940), the thinner peel (Sinclair, 1961), and the smaller overall physical distance isolating juice sacs of calamondin from the fruit exterior (stalks of individual sacs are shorter).

Estimated carbohydrate cost per gram of dry weight peaked during early fruit development in both grapefruit and calamondin (Table 1). The relatively high lipid content in the peel at this stage (Soule and Grierson, 1986) may contribute to a high growth cost.

Sugar: water influx into fruit. A curious aspect of sucrose and water entry into grapefruit was evident in the degree to which the ratio of net sucrose : water influx decreased after completion of fruit expansion (Table 2). Previous studies of sugar and water movement into citrus fruit tissues are consistent with this observation, although earlier work focused on juice sacs alone (Koch and Avigne, 1990; Koch et al., 1986). At the whole-fruit level, sugar entry would presumably occur via mass flow in the phloem. Maintenance of a Münch pressure flow requires a means to dissipate water arriving at the sink, either by transpiration, tissue expansion, or xylem back-flow. The first two of these have been accounted for in the present work. Together they can accommodate use of phloem water throughout most of citrus fruit development; however, for stage III grapefruit, this can occur only if one assumes to net water entry via xylem, and $1 \mathrm{~m}$ sucrose in the phloem sap. The latter is similar to the approximate maximum values reported for Citrus phloem by Zimmerman and Ziegler (1975). It is, therefore, possible for phloem alone to supply the calculated net daily water and sugar influx into maturing grapefruit. No other net water inflow was indicated at this stage of development, although xylem backflow (Elfving and Kaufmann, 1972) may have been an important avenue of exit for additional entering water.

\section{Literature Cited}

Bean, R. C., G.G. Porter, and B.K. Barr. 1963. Photosynthesis and respiration in developing fruit. III. Variation in photosynthetic capacities during color change in Citrus. Plant Physiol. 38:285-290.

Bean, R.C. and G.W. Todd. 1960. Photosynthesis and respiration in developing fruits. $\mathrm{L}^{14} \mathrm{CO}_{2}$ uptake by young orange in light and dark. Plant Physiol. 35:425-429.

Birkhold, K. T., K.E. Koch, and R.L. Darnell. 1992. Carbon and nitrogen economy of developing rabbiteye blueberry fruit. J. Amer. Soc. Hort. Sci. 117:139-145. 
Blanke, M.M. and F. Lenz. 1989. Fruit photosynthesis. Plant, Cell\& Environ. 12:31-46.

Blanke, M.M. and A. Leyhe. 1987. Stomatal activity of grape berry CV. Riesling, Muller-Thurgau and Ehrenfelser. J. Plant Physiol. 127:451-460.

Boyer, J.S. 1985. Water transport. Annu. Rev. Plant Physiol. 36:437516.

Cohen, Y., S. Moreshet, and M. Fuchs. 1987. Changes in hydraulic conductance of citrus trees following a reduction in wetted soil volume. Plant, Cell \& Environ. 10:53-57.

Daito, H. and Y. Sate. 1984. Respiration and ethylene evolution rates of satsumas harvested at different stages of development. J. Jpn. Soc. Hort. Sci. 53:308-313.

DeJong, T.M. and E.F. Walton. 1989. Carbohydrate requirements of peach fruit growth and respiration. Tree Physiol. 5:329-335.

Elfving, D.C. and M.R. Kaufmann. 1972. Diurnal and seasonal effects of environment on plant water relations and fruit diameter of citrus. J. Amer. Soc. Hort. Sci. 97:566-570.

El-Otmani, M., C.W. Coggins, Jr, and I.L. Eaks. 1986. Fruit age and gibberellic acid effect on epicuticular wax accumulation, respiration, and internal atmosphere of navel orange fruit. J. Amer. Soc. Hort. Sci. 111:228-232.

Flinn, A. M., C.A. Atkins, and J.S. Pate. 1977. Significance of photosynthetic and respiratory exchanges in the carbon economy of the developing pea fruit. Plant Physiol. 60:412418.

Ho, L. C., R.I. Grange, and A.J. Picken. 1987. An analysis of the accumulation of water and dry matter in tomato fruit. Plant, Cell \& Environ. 10:157-162.

Jones, H.G. 1981. Carbon dioxide exchange of developing apple (Malus pumila Mill) fruits. J. Expt. Bet. 32:1203-1210.

Kappes, E.M. 1985. Carbohydrate production, balance and translocation in leaves, shoots, and fruits of 'Montmorency' sour cherry. PhD Diss., Michigan State Univ., East Lansing.

Kaufmann, M.R. 1970. Water potential component in growing citrus fruits. Plant Physiol. 46:145-149.

Koch, K.E. and W.T. Avigne. 1990. Postphloem, nonvascular transfer in citrus: Kinetics, metabolism, and sugar gradients. Plant Physiol. 93:1405-1416

Koch, K. E., C.A. Lowell, and W.T. Avigne. 1986. Assimilate transfer through citrus juice vesicle stalks: A nonvascular portion of the transport path, p. 247-258. In: J. Cronshaw, W.T. Lucas, and R.T. Giaguinta (eds.). Plant biology, vol. 1: Phloem transport. Alan Liss, New York.
Kolattukudy, P.E. 1984. Biochemistry and function of cutin and suberin. Can. J. Bet. 62:2918-2933.

Mantell, A., E.E. Goldschmidt, and S.P. Monselise. 1980. Turnover of tritiated water in calamondin plants. J. Amer. Soc. Hort. Sci. 105:741-744.

Mitchell, P. D., P.H. Jerie, and D.J. Chalmers. 1984. Effects of regulated water deficits on pear tree growth, flowering, fruit growth, and yield. J. Amer. Soc. Hort. Sci. 109:604-606.

Morgan, J.M. 1984. Osmoregulation and water stress in higher plants. Annu. Rev. Plant Physiol. 35:299-319.

Pate, J. S., J. Kuo, and P.J. Hocking. 1978. Functioning of conducting elements of phloem and xylem in the stalk of the development fruit of Lupinus albus. Austral. J. Plant Physiol. 5:321-336.

Pate, J. S., P.J. Sharkey, and C.A. Atkins. 1977. Nutrition of a developing legume fruit, functional economy in terms of carbon, nitrogen, water. Plant Physiol. 59:506-510.

People, M: B., J.S. Pate, C.A. Atkins, and D.R. Murrang. 1985. Economy of water, carbon and nitrogen in the developing cowpea. Plant Physiol. 77:142-147.

Sinclair, W.B. 1961. Pectic substances, p. 191-229. In: W.B. Sinclair (cd.). The orange. Div. of Agr. Sci., Univ. of California, Riverside.

Sinclair, T.R. and L.H. Allen, Jr. 1982. Carbon dioxide and water vapor exchange of leaves on field grown citrus trees. J. Expt. Bet. 33:1166-1175.

Soule, J. and W. Grierson. 1986. Anatomy and physiology, p. 1-22. In: W.F. Wardowski, S. Nagy, and W. Grierson (eds.). Fresh citrus fruit. Van Nostrand Reinhold Co., New York.

Syvertsen, J.P. and L.G. Albrigo. 1980. Seasonal and diurnal citrus leaf and fruit water relations. Bet. Gaz. 141:440-446.

Turrell, F.M. and L.J. Klotz. 1940. Density of stomata and oil glands and incidence of water spot in the rind of' Washington' navel orange. Bet. Gaz. 101:862-871.

Wolterbeek, H. T., P.C.M. Willemse, and J. van Die. 1987. Phloem and xylem import of water and solutes in tomato fruits. Acts. Bet. Neerl. 36:295-306.

Yen, C.R. 1987. Assimilate partitioning and enzymes of organic acid metabolism in fruit of calamondin and low-acid grapefruit. $\mathrm{PhD}$ Diss., Univ. of Florida, Gainesville.

Zimmerman, M.H. and H. Ziegler. 1975. List of sugars and sugar alcoholsin sieve-tube exudates, p. 480-503. In: M.H. Zimmerman and J.A. Milbum (eds.). Transport in plants I: Phloem transport. Springer-Verlag, New York. 